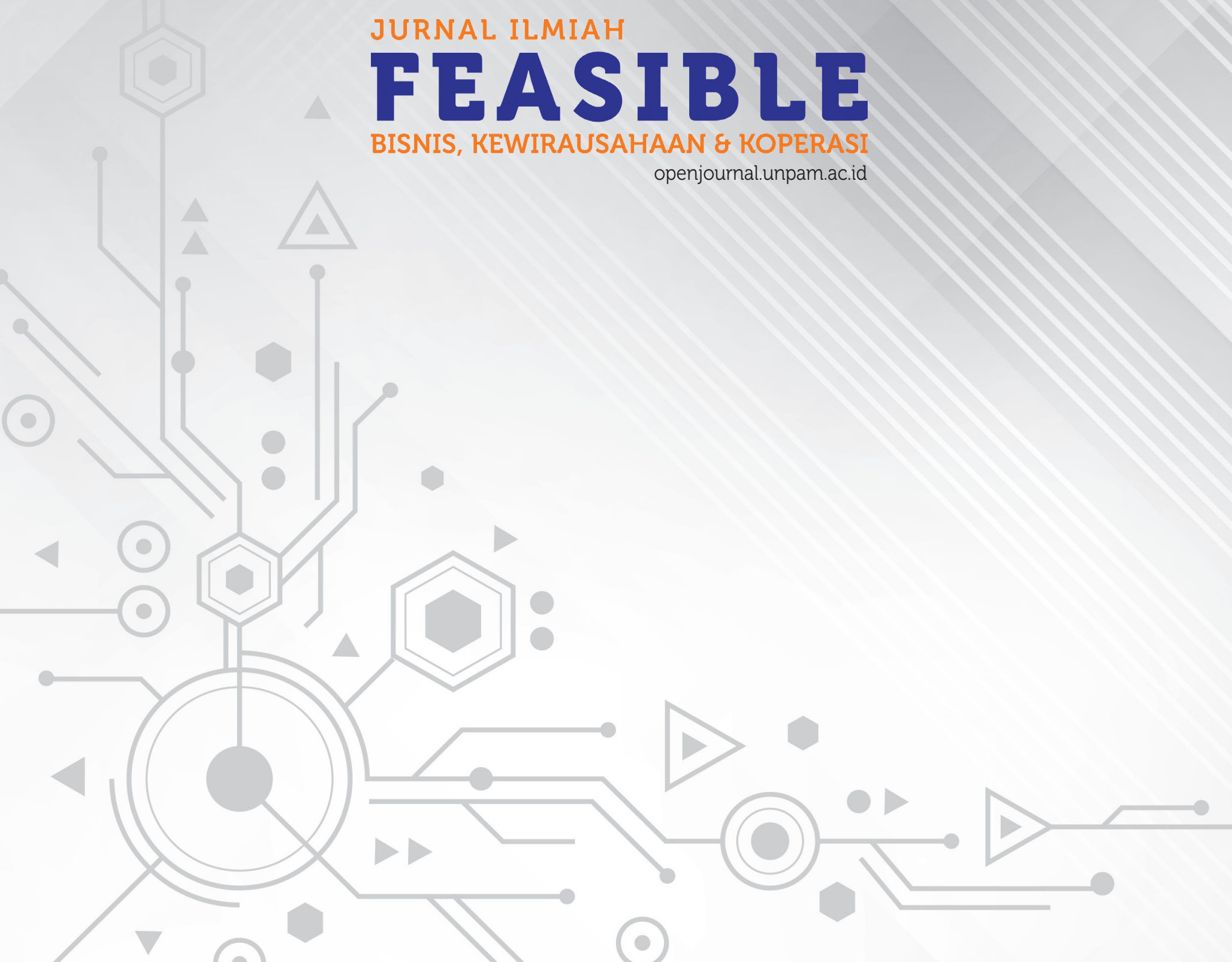




\title{
MEMBANGUN JIWA KEWIRAUSAHAAN BAGI MAHASISWA SEBAGAI UPAYA MEWUJUDKAN KEMANDIRIAN Perspektif Perkuliahan Mata Kuliah Kewirausahaan di Universitas Pamulang Tangerang Selatan
}

\author{
Teguh Yuwono \\ Dosen Program Studi Manajemen-Universitas Pamulang \\ teguh.yuwono9@yahoo.co.id
}

\begin{abstract}
Abstrak
Tujuan Praktik Perkuliahan Kewirausahaan adalah untuk mewujudkan kemandirian bagi para mahasiswa, sekaligus pembekalan ketrampilan berwirausaha. Hal ini penting karena selepas lulus kuliah mahasiswa tertuntut untuk melakukan kreativitas usaha agar dapat menghasilkan yang pada gilirannya dapat menghidupi dirinya sendiri, bermanfaat bagi lingkungan dan memberi dampak ekonomis bagi aktivitasnya. Metode yang dilaksanakan adalah dengan melakukan praktik bisnis dari produk yang sudah disiapkan oleh Koperasi Pusat Inkubasi Bisnis dan Kewirausahaan (Pinbik) Universitas Pamulang, yaitu yang tersedia di Kopinmart untuk dimarketingkan. Disinilah akan banyak kreativitas tercipta, baik penciptaan segmen, re-selling, sampai bagaimana melakukan positioning. Hasil daripembelajaran mata kuliah kewirausahaan dan sejenisnya-terlepas memenuhi target atau tidak - akan menjadi experience competence dan bahan evaluasi bagi para mahasiswa yang bersangkutan sekaligus penilaian bagi dosen pengampu mata kuliah kewirausahaan dan sejenisnya kepada mahasiswanya.
\end{abstract}

Kata kunci : Kewirausahaan, Kemandirian

\begin{abstract}
The purpose of the Entrepreneurship Lecture Practice is to create independence for students, as well as debriefing entrepreneurship skills. This is important because after graduating from college students are required to carry out business creativity so that they can produce, which in turn can support themselves, benefit the environment and have an economic impact on their activities. The method implemented is by conducting business practices from products that have been prepared by the Pamulang University Business and Entrepreneurship Incubation Center (Pinbik), which is available at Kopinmart for marketing. This is where a lot of creativity will be created, both segment creation, re-selling, and how to position. The results of learning entrepreneurship courses and the like - regardless of meeting the target or not - will become experience competence and evaluation material for the students concerned as well as assessing the lecturers of entrepreneurship courses and the like to students.
\end{abstract}

Keywords: Entrepreneurship, Independence

\section{LATAR BELAKANG}

Globalisasi telah meruntuhkan temboktembok penyekat antar bangsa, antar negara dan antar wilayah. Pergerakan barang, jasa dan investasi serta manusianya pun bergerak sangat cepat, maka persaingan di berbagai aspek kehidupan pun menjadi semakin ketat, terutama di bidang ekonomi terlebih bidang sumber daya manusianya.

Masalah global bidang ekonomi terlebih dengan diberlakukannya Masyarakat Ekonomi Asia (MEA) pada tahun 2015 lalu telah me- 
munculkan lebih banyak lagi pemain di sektor ekonomi yang memberi implikasi pada berbagai hal, seperti :

- Tuntutan customer yang makin complicated.

- Regulasi pemerintah yang makin ketat.

- Para pesaing dari luar negeri yang makin banyak.

- Customer demand yang makin kuat.

- Produk yang makin variatif.

- Tuntutan pelayanan yang makin prima.

- Tuntutan solution oriented.

Permasalahan diatas merupakantantangan yang tidak mudah dihadapi bagi para generasi muda yang kelak akan menggantikan generasi tua. Dan akan lebih sulit lagi bila pendidikan yang diajarkan kepada para generasi muda (pelajar dan mahasiswa) tidak diarahkan kepada pemahaman akan perubahan zaman yang sangat cepat.

Universitas Pamulang sebagai sebuah perguruan tinggi yang berada di bilangan Tangerang Selatan telah menorehkan sejarah sebagai perguruan tinggi yang memiliki jumlah mahasiswa sangat banyak. Menurut data terakhir (2018) jumlah mahasiswa Universitas Pamulang tidak kurang dari 80.000 mahasiswa. Hal ini tentu sebuah potensi yang luar biasa, namun muncul pertanyaan yang perlu dicermati : mau dikemanakan mereka semua setelah lulus kuliah? Apakah akan menjadi pengangguran inteketual atau malah menjadi aset yang membebani?. Permasalahan ini tentu harus dijawab bukan untuk dihindari atau mencoba dinisbatkan.

Memang sebagian mahasiswa yang belajar di Universitas Pamulang sudah bekerja, namun kebanyakan di sektor mikro dengan pendapatan atau upah yang didapatkannya hanya pas-pasan saja, sehingga bila upah yang didapatkan dipakai untuk biaya kuliah tentu pendapatannya menjadi kecil sekali. Lalu bagaimana yang belum bekerja, sedangkan setelah lulus mereka semua harus berjuang keras untuk bersaing dengan para lulusan perguruan tinggi yang lainnya guna memperebutkan peluang usaha atau lowongan kerja.

Kemampuan berwirausaha merupakan komponen yang sangat penting dalam menunjang pembangunan ekonomi. Apabila pembangunan di Indonesia ingin maju seperti negara lainnya, maka pembangunan kemampuan di bidang kewirausahaan harus dibina dan dimulai dari sekarang. Terkait dengan keberadaan mahasiswa di Universitas Pamulang, maka pembangunan kewirausahaan bagi mereka menjadi suatu pilihan wajib yang harus dilaksanakan. Maka untuk mengem- bangkan kewirausahaan, perlu disusun kurikulum yang memadai. Prinsipnya adalah para mahasiswa harus dibuat tertarik dan termotivasi untuk melihat adanya peluang atau kesempatan berbisnis yang menguntungkan (opportunity factors). Dengan demikian perkuliahan kewirausahaan tidak boleh hanya berhenti pada pemahaman teoritis di kelas saja. Mahasiswa harus memiliki beberapa keahlian seperti management skill, social skill, indutrial skill, organizasional skill, strategic skill, dan sebagainya. Dan pada gilirannya nanti akan menjadikan para mahasiswa mampu berkarir di dunia kerja dengan tahapan-tahapan yang sudah dipelajari atau praktikkan, yaitu :

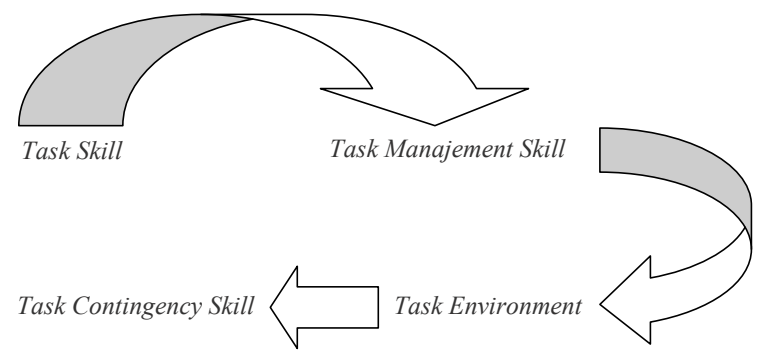

Persoalan yang muncul adalah bagaimana kesiapan Universitas Pamulang dalam mewujudkan jiwa kewirausahaan bagi para mahasiswa sekaligus sebagai "uniqueness of university". Maka tulisan ini diberi judul MEMBANGUN JIWA KEWIRAUSAHAAN BAGI MAHASISWA SEBAGAI UPAYA MEWUJUDKAN KEMANDIRIAN Perspektif Perkuliahan Mata Kuliah Kewirausahaan di Universitas Pamulang Tangerang Selatan.

\section{KEWIRAUSAHAAN}

Kewirausahaan merupakan kajian penting karena perannya dalam pembangunan ekonomi. Robbin \& Coulter, mengatakan bahwa "kewirausahaan merupakan suatu proses dimana seseorang ataupun suatu kelompok individu menggunakan upaya yang terorganisir dan sarana untuk mencari sebuah peluang dan menciptakan suatu nilai yang tumbuh dengan memenuhi kebutuhan dan keinginan melalui sebuah inovasi \& keunikan, tidak mempedulikan apapun sumber daya yang digunakan pada saat ini”. Berbeda dengan apa yang dipaparkan melalui "Keputusan Menteri Koperasi dan Pembinaan Pengusaha Kecil Nomor. 961/KEP/M/XI/1995 menyebutkan:

- Wirausaha adalah orang yang mempunyai semangat, sikap, perilaku dan kemampuan kewirausahaan.

- Kewirausahaan adalah semangat, sikap, perilaku dan kemampuan sesorang da- 
lam menangani usaha atau kegiatan yang mengarah pada upaya mencari, menciptakan serta menerapkan cara kerja, teknologi dan produk baru dengan meningkatkan efisiensi dalam rangka memberikan pelayanan yang lebih baik dan atau memperoleh keuntungan yang lebih besar. Dalam Wikipedia, "kewirausahaan didefinisikan secara lebih luas yaitu sebagai proses mengidentifikasi, mengembangkan, dan mewujudkan visi ke dalam kehidupan". Dari beberapa makna yang disebutkan di atas, maka jika suatu negara memiliki banyak wirausaha, negara tersebut akan memiliki pertumbuhan ekonomi yang tinggi, dan tentunya akan mendorong perkembangan ekonomi yang tinggi pula. Jika suatu negara ingin maju, harus ada banyak pengusaha. "Kewirausahaan adalah kekuatan pendorong di belakang pertumbuhan ekonomi", Kirzner berpendapat, menambahkan bahwa kewirausahaan adalah bagian penting dari pembangunan.

Masuk akal jika seseorang memiliki kewirausahaan, ia akan memiliki karakteristik semangat tinggi (need of achievement), berani mencoba (risk taker), inovative, dan independence. Sesuai sifatnya, dengan hanya beberapa peluang dan peluang, ia mampu mengubah, menghasilkan sesuatu yang baru, hubungan baru, mengakumulasi modal, baik dalam bentuk perbaikan bisnis yang ada (misalnya reseller) dan menghasilkan bisnis baru. Dengan upaya ini, ia akan mendorong penawaran dan promosi sehingga pada akhirnya konsumen ingin membelinya. Dalam proses ini akan terjadi pertukaran barang dan jasa, baik dalam bentuk uang, sumber daya sosial, dan sumber daya manusia. Dalam ekonomi, jika sesuatu terjadi, itu berarti ada pertumbuhan ekonomi, dan jika ada pertumbuhan ekonomi, itu berarti ada pembangunan.

\section{SK REKTOR SEBAGAI}

\section{DASARPRAKTIKKEWIRAUSAHAAN}

Mensikapi pergerakan Masyarakat Ekonomi Asia yang terus bergulir dengan segala implikasinya, maka Universitas Pamulang membuat terobosan strategik melalui perkuliahan praktik untuk mata kuliah kewirausahaan dan sejenisnya. Hal ini tentu harus memiliki payung hukum, sebagaimana studi kelayakan bisnis, semua usaha yang dilakukan harus legal. Melalui SK Rektor No. 129/A/LL/ UNPAM/II/2018 tentang Pembelajaran dan Sertifikasi Praktik Kewirausahaan atau Mata Kuliah Sejenis, Pusat Inkubasi Bisnis dan Kewirausahaan (Pinbik) Universitas Pamulang bergerak cepat mengimplementasikan SK tersebut dengan membuat Labik (Laboratorium Bisnis dan Kewirausahaan). Bunyi SK tersebut yang dijadikan dasar hukum praktik kewirausahaan, yaitu : "Setiap mahasiswa diwajibkan memiliki minimal 1 (satu) Sertifikat/ Surat Keterangan Praktek Kewirausahaan sebagai salah satu syarat pengajuan sidang skripsi/tugas akhir".

\section{KOPINMART - LABORATORIUM BISNIS DAN KEWIRAUSAHAAN}

Kopinmart adalah sebuah tempat atau wadah para mahasiswa belajar untuk memarketingkan produk-produk yang telah disediakan. Maka fungsi Kopinmart adalah sebagai Laboratorium bisnis dan kewirausahaan para mahasiswa. Dari sini mahasiswa akan di dorong memiliki kemampuan dasar menjadi seorang wirausaha, seperti :

- kemampuan pemasaran,

- kemampuan teknis/operasional,

- kemampuan bagaimana mengelola keuangan,

- kemampuan melakukan networking/kemitraan,

- $\quad$ komunikasi/negosiasi, dan sebagainya.

Mendasarkan pada pemahaman tersebut, jelas sekali bahwa keberadaan kopinmart menjadi strategis sifatnya. Demikian pula praktek kewirausahaan yang diprogramkan pun menjadi sangat penting untuk dilaksanakan. Mahasiswa bukan saja akan memiliki pengalaman yang sangat berarti mempraktekkan teori keilmuannya namun hal tersebut akan menguatkan mental dan keyakinannya untuk bisa menjadi seorang wirausaha.

\section{ANALISIS TEORI DAN PRAKTEK}

Patut disadari bahwa antara teori dan praktek sering terjadi ketidakselarasan, atau adanya kesenjangan nilai. Hal ini penulis gambarkan dalam skema sebagai berikut :

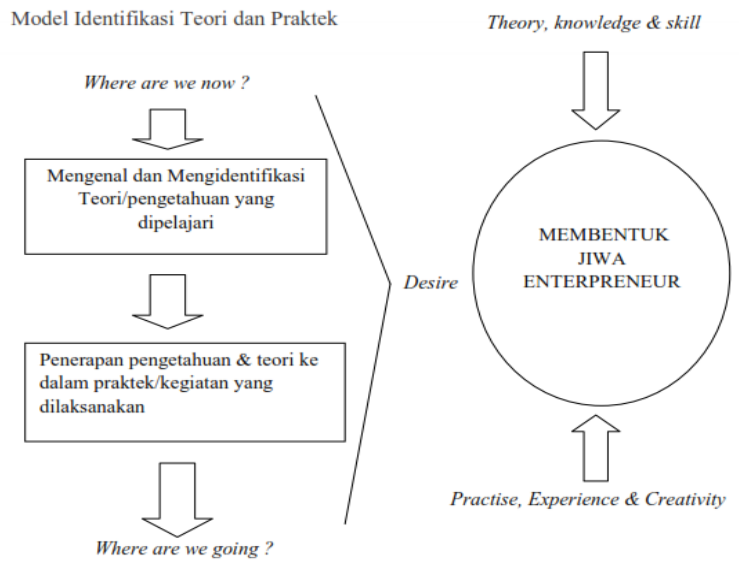


Penjelasan :

Pada awalnya mahasiswa belajar dari teori-teori atau pengetahuan yang di dapatkan dari dosen atau di kelas. Lalu mengidentifikasi persoalan-persoalan yang terkait dengan kewirausahaan. Mendasarkan apa yang dipelajari, maka mahasiswa mulai melakukan praktek kewirausahaan. Tentu antara teori dan praktik tidak selalu selaras dapat terimplementasikan dengan tepat. Selalu ada kondisi-kondisi tertentu yang perlu disikapi secara kreatif, sehingga menimbulkan semangat pembentukan mental baru, sikap baru, kebiasaan baru dan pandangan baru yang pada gilirannya melalui sinergi antara teori, keterampiran dan pengetahuan dengan praktek, pengalaman dan kreativitas akan membentuk jiwa kewirausahaan.

\section{TANTANGAN KEWIRAUSAHAAN}

Sebagai bagian dari pemuda, mahasiswa merupakan modal dasar dalam pengembangan pemecahan berbagai permasalahan bangsa, dan bukan sebaliknya justeru menjadi problem dari bangsa ini. Terlebih lagi, jika mengingat dunia ketenagakerjaan yang belum menjamin ketersediaan lapangan pekerjaan yang memadai bagi mahasiswa terutama pada saat menyelesaikan masa kuliah. Persoalan penyediaan lapangan pekerjaan menjadi salah satu masalah mendasar dalam pembangunan nasional berkelanjutan. Hal tersebut erat kaitannya dengan kenaikan intensitas persoalan pengangguran.

Tantangan yang paling berat dalam mengembangkan kewirausahaan pada kalangan mahasiswa dikarenakan keterbatasan dalam hal: keberlanjutan usaha, modal produksi, keahlian kerja, kualitas produk, jaminan pasar produk dan kemitraan yang minim. Tentu saja berbagai permasalahan tersebut merupakan tantangan berat bagi mahasiswa yang ingin mengembangkan jiwa dan semangat wirausaha. Apalagi bagi mahasiswa reguler $\mathrm{C}$ yang hampir tidak ada waktu untuk belajar kewirausahaan. Tiap senin sampai jumat bekerja di kantornya dan sabtu dari pagi sampai sore kuliah. Sehingga praktis hanya punya waktu hari minggu.

\section{MENJAWAB TANTANGAN}

Persoalan-persoalan atau tantangan-tantangan yang terkait dengan masa depan generasi muda pada umumnya dan mahasiswa Universitas Pamulang pada khususnya harus ada penanganan yang berkelanjutan dan tidak dapat dibiarkan berlangsung terus. Solusi yang perlu dikedepankan diantaranya me- ngembangkan jiwa, semangat dan perilaku kewirausahaan sebagai bagian dari aktivitas "generasi muda penerus cita-cita bangsa dan negara. Pengembangan kesadaran dan motif kewirausahaan pada kalangan mahasiswa merupakan suatu kebutuhan mendasar untuk Inovasi dan Kewirausahaan," terutama dalam "mencapai peningkatan kualitas sumberdaya manusia agar nantinya selain terlahir sebagai insan terdidik juga berkarakter mandiri, ulet, bekerja keras, pantang menyerah, bertanggungjawab, berani menanggung risiko, bermotif ekonomi, menghargai waktu dan memanfaatkan setiap kesempatan, produktif, kreatif dan inovatif." Pengembangan kewirausahaan pada kalangan mahasiswa memerlukan ragam terobosan jitu yang tepat guna dan tepat sasaran. Dan pada gilirannya nanti meskipun memiliki waktu yang terbatas (kelas Reguler C) tetap dapat memanage nya dengan baik, karena telah tertanamnya jiwa kewirausahaan.

\section{PERSPEKTIF PENULIS}

"Kemiskinan sangat erat kaitannya dengan ketiadaan kewirausahaan. Oleh karena itu, keberadaan kewirausahaan mulai dari level individu, organisasi sampai masyarakat sangat terkait erat dengan miskin atau tidaknya masyarakat. Jika kewirausahaan tinggi, maka kemiskinan akan rendah.”

"Jadikan kewirausahaan sebagai jiwa, semangat dan perilaku mahasiswa pada khususnya dan mentalitas masyarakat Indonesia pada umumnya. Momen ini mestinya jangan sampaiterputus darimulai proses pembentukan mindset dan awareness kewirausahaan, rencana aksi dan praktek kewirausahaan sampai pada tingkat realisasi aksi dan sekaligus evaluasi secara terpadu."

\section{SIMPULAN}

Sebagai bagian akhir dari tulisan ini penulis ingin memberikan 4 penekanan yang bisa dimaknai sebagai kesimpulan, yaitu :

1. "Pengembangan jiwa, semangat dan perilaku kewirausahaan pada mahasiswa merupakan salah satu kebutuhan mendasar dan syarat penting bagi bangsa Indonesia sehubungan dengan tujuan peningkatan kualitas sumberdaya manusia yang produktif, kreatif dan inovatif.

2. Berbagai permasalahan yang merintangi pengembangan kewirausahaan mahasiswa perlu diantisipasi secara bijak dalam rangka menemukan solusi yang tepat. “

3. Membangun "semangat kewirausahaan 
pada mahasiswa membutuhkan komitmen dan kerjasama yang integratif antar berbagai pihak terkait.

4. Proses pengembangan kewirausahaan pada mahasiswa perlu dilaksanakan secara berkelanjutan sebagai proses sejak dini memasuki pendidikan di perguruan tinggi, learning by doing sampai mencapai kelulusan sebagai sarjana."

\section{DAFTAR PUSTAKA}

Sunaryo, Yusuf. 2016. "Kewirausahaan Dari Teori Ke Praktik”. Pe\#ko Pers : Tangerang Selatan.

Suryana, Yuyus dan Khatib Bayu. 2013. "Kewirausahaan-Pendekatan Karakteristik Wirausahawan Sukses”. Kencana Prenada Media Group : Jakarta.

http://www.spengetahuan.com/2015/03/18pengertian-kewirausahaan-menurut-paraahli.html

https://www.scribd.com/doc/261069901/ pentingnya-kewirausahaan 